\title{
Pregestasyonel Diyabet ve Fetal Programlama
}

\author{
Pregestational Diabetes and Fetal Programming
}

\author{
Büşra Aslan ${ }^{1}$ Zeynep Caferoğlu ${ }^{2}$
}

Geliş tarihi/Received: 26.06.2020 • Kabul tarihi/Accepted: 17.12.2020

\section{ÖZET}

Pregestasyonel diyabetli gebelerde maternal, fetal ve neonatal komplikasyonların ortaya çıkma riski artmaktadır. İntrauterin çevre; gen ekspresyonundaki değişiklikler, oksidatif stres ve epigenetik modifikasyon gibi yolaklar üzerinden fetal programlanmaya katkıda bulunur. Özellikle fetüsün maternal dönemde hiperglisemi ile karşılaşmış olması intrauterin çevresi için endişe verici bir konudur. Bu nedenle hiperglisemi riski olan bireylerde, gebelik öncesi dönemde glisemik kontrol sağlanana kadar aile planlaması yapılmalıdır. Gestasyonel dönemde ise fetal riskleri ve gebelik komplikasyonlarını en aza indirgeyebilmek için ortalama kan glukoz düzeyi $100 \mathrm{mg} / \mathrm{dL}$ ( $5.6 \mathrm{mmol} / \mathrm{L}$ ) ve HbA1c değeri <\%6 seviyelerinde tutulmalıdır. Fetal programlamanın etkisi anne karnındaki olumsuz çevresel koşullara maruziyet süresi ile yakından ilişkilidir. Diyabetik ortam, anne ve fetüs arasında kanal görevi gören plasentada değişikliklere neden olarak erken dönemde gebelik kaybı, büyümenin kısıtlanması, preeklampsi riskinin artışı ve plasentomegaliye yol açabilir. Bu derlemenin amacı, pregestasyonel diyabetli gebelerde fetal programlamanın sonuçları hakkında genel bir bakış açısı sağlamaktır.

\section{Anahtar kelimeler: Pregestasyonel diyabet, fetal programlama, maternal hiperglisemi}

\section{ABSTRACT}

The risk of maternal, fetal and neonatal complications increase in pregnant women with pregestational diabetes. The intrauterine environment contributes to fetal programming from pathways such as changes in gene expression, oxidative stress and epigenetic modification. Fetus facing hyperglycemia during maternal period is a challenging factor for intrauterine environment. Therefore, family planning should be done in individuals with hyperglycemia risk, until glycemic control is achieved in the prenatal period. In the gestational period, the average blood glucose level should be maintained at $100 \mathrm{mg} / \mathrm{dL}$ ( $5.6 \mathrm{mmol} / \mathrm{L}$ ) and $\mathrm{HbA1c}<6 \%$ in order to minimize fetal risks and pregnancy complications. The effect of fetal programming is closely related to the duration of exposure to environmental conditions in the uterus. The diabetic environment may cause pregnancy loss, restriction of growth, increased risk of preeclampsia and placentomegaly by causing changes in the placenta, which acts as a channel between the mother and fetus. The aim of this review is to provide an overview of the results of fetal programming in pregnant women with pregestational diabetes.

Keywords: Pregestational diabetes, fetal programming, maternal hyperglycemia

1. İletişim/Correspondence: Erciyes Üniversitesi, Sağllk Bilimleri Fakültesi, Beslenme ve Diyetetik Bölümü, Kayseri, Türkiye

E-posta: dytbusraslan@gmail.com • $\odot$ https://orcid.org/0000-0002-2365-3069
2. Erciyes Üniversitesi, Sağllk Bilimleri Fakültesi, Beslenme ve Diyetetik Bölümü, Kayseri, Türkiye • ๑ https://orcid.org/0000-0002-7226-5636 


\section{GíRiş}

Diabetes Mellitus (DM), vücutta insülin üretiminin hiç olmaması veya yetersiz olması nedeniyle ortaya çıkan yüksek kan glukozu ile karakterize ciddi, kronik ve metabolik bir hastalıktır (1). Uluslararası Diyabet Federasyonu (International Diabetes Federation, IDF)'nun 2019 yllı verilerine göre; 20.4 milyon (\%15.8) canlı doğumun gebelikte hiperglisemiye maruz kaldığı tahmin edilmektedir. Buvakaların \%83.6'sıgestasyonel DM iken, \%7.9'u pregestasyonel DM ve \%8.5’i ilk kez gebelikte tespit edilen tip 1 ve tip 2 DM'dir. Yine IDF'e göre, 2030 ve 2045 yıllarında sirasıyla 18.3 milyon ve 18.0 milyon canlı doğumun gebelikte hiperglisemiye maruz kalacağı tahmin edilmektedir (1). Gebelik öncesinde tip 1 veya tip 2 DM tanısı almış bir kadının gebelik dönemindeki diyabeti 'pregestasyonel DM' olarak tanımlanmaktadır (2). Pregestasyonel tip 1 DM, pankreatik § hücre hasarı ile karakterize ve genellikle hayatın erken döneminde ortaya çıkan otoimmün bir durumdur. Pregestasyonel tip $2 \mathrm{DM}$ ise diyabetik gebeliklerin en yaygın görülen türü olmakla birlikte yaşamın ilerleyen dönemlerinde başlaması, periferik insülin direnci, göreceli insülin eksikliği ve obezite ile karakterizedir (3). Pregestasyonel DM'li gebelerde; perinatal mortalite artışı, konjenital anomaliler, fetal büyüme geriliği, erken doğum, makrozomik bebek ve sezaryen doğum riski artmaktadır (4). Bu derlemenin amacı, pregestasyonel DM'li gebelerde fetal programlamanın sonuçları hakkında genel bir bakış açısı sağlamaktır.

\section{MATERNAL VE FETAL KOMPLIKASYONLAR}

Pregestasyonel DM'li gebelikler, retinopati ve nefropati gibi DM komplikasyonlarının şiddetlenmesi ile ilişkilendirilmiştir (5-7). Kötü glisemik kontrol ve hipertansif bozukluklar, gebelik sirasinda retinopatinin ilerlemesine neden olabilmektedir. Gebelik öncesi diyabetik nefropatisi olan kadınlar hipertansif bozukluklar, uteroplasental yetmezlik ve erken doğum dahil olmak üzere olumsuz obstetrik komplikasyonlar için daha yüksek risk altındadır. Nefropati, gebeliklerin \%10’unu etkileyebilmektedir.
Pregestasyonel DM'li gebelerin \%5-10'unu etkileyerek; preeklampsi, uteroplasental yetmezlik ve ölü doğum gibi riskleri artıran bir diğer komplikasyon ise kronik hipertansiyondur (8). Yapılan geniş çaplı bir çalışmada (9), gestasyonel DM'li ve pregestasyonel tip 2 DM'li gebe kadınların maternal sonuçları karşılaştırılmıştır. Buna göre tip 2 DM'li kadınlarda; preeklampsi gibi hipertansif bozukluklar, erken doğum ve sezaryen riskinin gestasyonel DM'li kadınlara göre anlamlı olarak daha yüksek oranda görüldüğü belirlenmiştir (9). Bunlara ek olarak; pregestasyonel DM'li gebelerde akut miyokard infarktüsü, diyabetik ketoasidoz ve koroner arter hastalığı görülme riski de artmaktadır (8).

Pregestasyonel DM'nin fetal büyüme üzerindeki en yaygın etkisi, gebelik yaşına göre iri bebek (Large for Gestational Age, LGA) doğurma öyküsüdür. Makrozomi; plasenta boyunca glukoz difüzyonunun kolaylaşması sonucu, fetal hiperglisemiye neden olması ile açıklanmaktadır. Fetal pankreas § hücrelerinin uyarılması, fetal büyüme ve artmış yağ kütlesi ile ilişkilendirilmiştir (9). Bu durum gebeliklerin \%40-50'sinde görülmektedir (10). Bunun aksine; gebede retinopati, nefropati veya kardiyovasküler/hipertansiyon gibi komorbiditeler yoksa fetal büyüme geriliği ve gebelik yaşına göre küçük bebek (Small for Gestational Age, SGA) nadiren görülmektedir (4). Pregestasyonel tip 2 DM’li kadınlar ve gestasyonel DM'li kadınların neonatal sonuçlarının karşılaştırıldığı bir çalışmada (9), gruplar arasında ölü doğum, neonatal yoğun bakım başvuru sıklığı ve SGA görülme sıklığında istatistiksel olarak önemli bir fark bulunmamıştır. Ancak makrozomi, LGA, sarılık ve respiratuvar distres sendromu tip 2 DM'li kadınlarda gestasyonel DM'li kadınlardan önemli olarak daha yüksek görülmüştür (9).

Konjenital anomali ile doğan çocuk sayısındaki artışta DM’nin önemli bir rolü olduğu düşünülmektedir. Pregestasyonel DM, doğum defektleri artışı ile yakından ilişkili olup nöral tüp defekti, holoprozensefali, majör kardiyak anomalileri, 
eksomfalos ve bilateral renal agenez gibi defektler için riski 10 kattan fazla artırmaktadır (4). Pregestasyonel DM'li kadınların çocuklarında, gestasyonel DM'lilere göre \%35 ve sağlıklı kontrollerine göre \%50 daha fazla yenidoğan morbiditesi görülme riski bulunmaktadır (11). Kötü kontrollü gestasyonel DM'nin sonucu olarak, yenidoğanlarda kısa ve uzun dönemli etkiler görülebilmektedir. Kısa dönemde; şiddetli hipoglisemi, respiratuvar distres sendromu, polisitemi, organomegali, elektrolit bozuklukları ve hiperbilirubinemi sorunları ortaya çıkabilir. Uzun vadeli olumsuz sonuçlar ise karbonhidrat intoleransı, obezite, çocukluk döneminde otizm, erişkin dönemde metabolik sendrom ve kalp hastalıkları görülme riskidir (8). HbA1c (glikozillenmiş hemoglobin) değeri \%6.9'a ulaştığında fetal anomali riski artış gösterirken, \%10.4'e ulaştığında majör anomali oranı \%10'un üzerine çlkabilmektedir (4). Diyabetik gebeliklerde ortaya çıkması muhtemel maternal, fetal ve neonatal komplikasyonlar Tablo 1'de özetlenmiştir.
Prenatal dönemde maternal DM’ye maruz kalmanın, fetal büyümeyi etkilediği düşünülen olası mekanizmalar karmaşık ve çok faktörlüdür. $\mathrm{Bu}$ mekanizmalar; kritik yolaklarda yer alan genlerin ekspresyonundaki değişiklikler, oksidatif stres ve epigenetik modifikasyonu içermektedir (4,1214). Maternal DM, embriyogenez için gerekli olan sinyal ve metabolik yolaklarda yer alan genlerin ekspresyonunu değiştirebilmektedir. Oksidatif stres DNA hasarına neden olarak protein/lipit oksidasyonuna, reaktif oksijen türlerinin artışına ek olarak nitrik oksitin biyoyararlanımındaki azalmayla, endotel disfonksiyona yol açmaktadır. DNA metilasyonu ve histon modifikasyonu gibi epigenetik değişiklikler, büyüme ve gelişmeyle ilgili genlerin ekspresyonunun düzenlenmesinde rol oynamaktadır (4).

Tablo 1. Diyabetik gebeliklerde ortaya çıkması muhtemel maternal, fetal ve neonatal komplikasyonlar $(4,8,9,11)$

\begin{tabular}{ll}
\hline Maternal & Diyabetik komplikasyonların şiddetlenmesi (retinopati, nefropati) \\
& Preeklampsi \\
& Uteroplasental yetmezlik \\
& Ölü doğum \\
& Akut miyokard infarktüsü \\
& Diyabetik ketoasidoz \\
& Diyabetik arter hastalı̆̆ \\
\hline Fetal & Makrozomi \\
& İntrauterin büyüme geriliği \\
& Fetal anomaliler (nöral tüp defekti, holoprozensefali, majör kardiyak anomalileri, eksomfalos, bilateral \\
& renal agenezi vb.) \\
& İntrauterin ölüm \\
\hline Siddetli hipoglisemi \\
Respiratuvar distres sendromu \\
Polisitemi \\
Organomegali \\
Elektrolit bozuklukları \\
Hiperbilirubinemi \\
Karbonhidrat intoleransı \\
Obezite \\
Otizm \\
Metabolik Sendrom \\
Kalp hastalıkları \\
\hline
\end{tabular}




\section{GESTASYONEL DIYABET YÖNETIMI}

Gebeliğin prognozunu belirlemek için; anne adayının DM tanısı konulduğu andaki yaşı, DM süresi, eşlik eden makrovasküler ve mikrovasküler komplikasyonlar ve bunların derecesi kullanılmaktadır. Bu kapsamda geliştirilen modifiye "White sinıflaması" Tablo 2'de gösterilmiştir. Pregestasyonel DM'li kadınların takibinde bu sinıflandırma kullanılarak gebelik prognozunun takibi önerilmektedir. Bu sinıflamaya göre, D grubu ya da daha ileri dönemlerde gebelik prognozunun kötü olduğu anlaşılmaktadır (15).

\section{Gebelik Öncesinde Diyabetin Yönetimi}

Pregestasyonel dönemde, bireylerin optimal glisemik kontrol sağlanana dek uygun doğum kontrol yöntemi ile aile planlaması yapması çok önemlidir. Diyabet yönetiminde, yaşam tarzı değişiklikleri önerilmektedir. $\mathrm{Bu}$ değişiklikler, beslenme tedavisi ve egzersiz kombinasyonu ile optimal glisemik kontrole odaklanmaktadır (8). Çeşitli kılavuzlara göre $(3,16,17)$, pregestasyonel dönemdeki danışmanlık ile glukoz yönetiminin sağlanması, maternal ve fetal komplikasyon riskini en aza indirmektedir. Amerikan Diyabet Birliği (American Diabetes Association, ADA) ve Ulusal Sağlık ve Klinik Mükemmellik Enstitüsü (National Institute for Health and Care Excellence, NICE) pregestasyonel dönemde HbA1c seviyelerinin \%6.5'dan az olması gerektiğini belirtirken, Amerikan Kadın Hastalıkları ve Doğum Koleji (American College of Obstetricians and Gynecologists, ACOG) \%6'dan az olması gerektiğini belirtmektedir.

\section{Gebelikte Diyabet Yönetimi}

Gestasyonel dönemde kırmızı kan hücreleri döngüsünün artması nedeniyle $\mathrm{HbA1C}$ seviyeleri düşmektedir. $\mathrm{Bu}$ nedenle, sadece HbA1c ölçümü ile hipo/hiperglisemi tam olarak anlaşılamadığı için HbA1c ölçümü glisemik kontrolün ikincil bir göstergesi olarak kullanılmaktadır $(16,18)$. Bu dönemde sürekli glukoz izlemi ile optimal HbA1c ve kan glukoz değerlerine ulaşılması önerilmektedir. Tip 1 ve tip 2 DM’li kadınlar için hedef kan glukoz değerleri; açlık < $95 \mathrm{mg} / \mathrm{dL}$ (5.3 mmol/L), 1. saat postprandial $<140 \mathrm{mg} /$ $\mathrm{dL}(7.8 \mathrm{mmol} / \mathrm{L})$ ve 2 . saat postprandial $<120 \mathrm{mg} / \mathrm{dL}$ (6.7 mmol/L) olarak belirlenmiştir (16). Fetal riskleri ve gebelik komplikasyonlarını en aza indirmek için ise ortalama kan glukoz düzeyinin $100 \mathrm{mg} / \mathrm{dL}$ (5.6 mmol/L) ve HbA1c'nin \%6'dan düşük olması gerektiği belirtilmektedir. Ek olarak, embriyogenez öncesi veya sirasında glisemik kontrole yapılan agresif yaklaşımlar da fetal anomali riskini azaltabilmektedir (3).

\section{TEDAVi}

Oral antidiyabetikler, hem insülin direncini tedavi etmede yetersiz kaldıkları için hem de fetüs gelişimini etkileyeceklerinden gebelik döneminde tercih edilmemektedir $(16,19)$. Bu nedenle, tip 1 ve tip 2 DM’li gebelerin tedavisinde insülin kullanılmaktadır (16).

Tablo 2. Modifiye White Sinıflaması (15)

\begin{tabular}{lll}
\hline & Grup & \multicolumn{1}{c}{ Sınıf } \\
\hline Gestasyonel & A1 & Herhangi bir yaş ve sürede, yalnız diyetle regüle \\
Diyabet & A2 & Herhangi bir yaş ve sürede, diyet + insülin ile tedavi edilen \\
Pregestasyonel & B & Diyabet tanısındaki yaşı $\geq 20$ yll ve diyabet süresi $<10$ yll, komplikasyonsuz \\
Diyabet & C & Diyabet tanısındaki yaşı veya diyabet süresi: 10-19 yll, komplikasyonsuz \\
& D & Diyabet tanısındaki yaşı <10 yıl veya diyabet süresi $\geq 20$ yll \\
& F & Herhangi bir yaş ve sürede, insülin tedavisinde, nefropati (>500 mg/gün protein) var. \\
& R & Herhangi bir yaş ve sürede, insülin tedavisinde, proliferatif retinopati var \\
& RF & Herhangi bir yaş ve sürede, insülin tedavisinde; R ve F sinıfındaki özelliklerin bir arada bulunması \\
& H & Klinik olarak tespit edilmiş aterosklerotik kalp hastalığı \\
& T & Renal transplantasyon öyküsü \\
\hline
\end{tabular}




\section{İnsülin Tedavisi}

İnsülin, plasentayı geçmediği için sıklıkla tercih edilen farmakolojik ajandır. Gebeliğin ilk üç aylık döneminde insülin gereksinmesinde bir artış olurken 9-16. haftalarda azalma meydana gelmektedir. On altı haftadan sonra hızla artan insülin direnci nedeniyle, insülin dozunda haftalık \%5 artış gerekebilmektedir (16). Üçüncü trimesterde yaklaşık iki katına çıkabilen insülin gereksinmesi sonucu insülin tedavisi; ilk trimesterde 0.7-0.8 ünite $/ \mathrm{kg} /$ gün, ikinci trimesterde 0.8-1 ünite/kg/gün iken, üçüncü trimesterde 0.9-1.2 ünite/kg/gün aralığında olmalıdır (3). Toplam insülin dozunun \%50'den azı bazal ve \%50'den fazlası bolus insülin olarak verilmelidir. Gebelik fizyolojisi nedeniyle değişen gereksinimlere cevap verebilmek için kan glukoz takibinin sık aralıklarla yapılması önemlidir. Gebelere, kendi kendine glukoz izleminin önemi mutlaka anlatılmalı ve izleme teşvik edilmelidir (16).

\section{Egzersiz Tedavisi}

Fiziksel egzersiz, insülin duyarlılığını arttırmaktadır (20). Kontrendikasyonları olmayan tüm gebelere, 20-30 dakika orta derecede aerobik, direnç veya kas güçlendirme egzersizleri önerilmelidir. Yürüyüş, yüzme, pilates ve yoga gibi egzersizler uygun iken grupla yapılan sporlar, dalış ve uçuş uygun değildir (15). Tip 1 DM'li gebelerde fiziksel aktivitenin glisemiye etkisi ve besin/insülin ayarlamalarının net olarak anlatılması önemlidir. Fiziksel aktivite sırasında sürekli glukoz izlemesi ile ortaya çıkabilecek hipoglisemi riskinin önüne geçebilir. Kan glukoz düzeylerinin ortalama $120 \mathrm{mg} / \mathrm{dL} \quad$ (6.7 mmol/L) düzeylerinde kalması sağlanmalıdır. Özellikle gece yapılan egzersizlerde noktürnal hipoglisemi fark edilemeyebilir. Bu nedenle; egzersizin türü, yoğunluğu ve süresi göz önünde bulundurularak egzersiz öncesi, sırası ve sonrasında kan glukoz izlemi yapılmalıdır. Tip 2 DM'li gebelerde fiziksel aktivite; optimal glisemik kontrol, kardiyovasküler risk faktörlerinde azalma ve vücut ağırlık kaybı ile ilişkilidir (20).

\section{Tıbbi Beslenme Tedavisi}

Pregestasyonel DM'li gebelerde karbonhidrat alımının kontrol altında olduğu bir beslenme tedavisi önerilmektedir. Bu süreçte, diyetisyen ve/veya DM eğitimcisi ile çalışmak oldukça önemlidir (3). İlk olarak gebenin beslenme öyküsü almarak, besin tüketimindeki yeterlilik ve beslenme alışkanlıkları belirlenmelidir. $\mathrm{Bu}$ belirlemelere göre, sağlıklı beslenme hedefleri oluşturularak eğitim ve tedavi planı oluşturulmalı ve izlem yapılmalıdır. $\mathrm{Bu}$ gebelerde tıbbi beslenme tedavisi; uygun vücut ağırlığı artışı, normoglisemi ve idrarda keton oluşturmamaya odaklanmaktadır. Gebelik öncesi vücut ağırlığı ve uygun vücut ağırlık artışı planlanarak annenin enerji gereksinmesi hesaplanmalıdır (21). Enerji gereksinmesi; annenin yaşı, aktivite düzeyi, şu andaki vücut ağırlığı ve gebelik yaşına göre değişmektedir. Sağlıklı gebelerde olduğu gibi DM'li gebelerde de enerji gereksinmesi, gebelik öncesi beden kütle indeksi (BKİ) kullanılarak belirlenmektedir (19). Gebelik önceki BKİ’ye göre istenilen vücut ağırlık kazanımı miktarları Tablo 3’te gösterilmiştir. Gebelik boyunca vücut ağırlık kazanımı en az 5-9 kg olmalıdır (22). Gebelik süresince meydana gelen fizyolojik değişiklikler nedeniyle enerji gereksinmesi, ikinci trimesterde $340 \mathrm{kkal} / g u ̈ n$ ve üçüncü trimesterde 452 kkal/gün artmaktadır (21). Enerji kısıtlaması ve aşırı beslenmenin maternal ve fetal etkilerinden kaçınmak için yeterli ve dengeli beslenme teşvik edilmelidir (11).

Tablo 3. Gebelerde uygun ağırlık kazanımı (22)

\begin{tabular}{|c|c|c|}
\hline Gebelik Öncesi BKİ (kg/m²) & $\begin{array}{l}\text { Gebelik boyunca önerilen vücut } \\
\text { ağırlık kazanımı (kg) }\end{array}$ & $\begin{array}{l}\text { İkinci ve üçüncü trimesterde haftalık } \\
\text { ortalama vücut ağırlık kazanımı (kg/hafta) }\end{array}$ \\
\hline$<18.5 \mathrm{~kg} / \mathrm{m}^{2}$ (Zaylf) & $12.5-18 \mathrm{~kg}$ & $0.51(0.44-0.58) \mathrm{kg} / \mathrm{hafta}$ \\
\hline $18.5-24.9 \mathrm{~kg} / \mathrm{m}^{2}$ (Normal) & $11.5-16 \mathrm{~kg}$ & $0.42(0.35-0.50) \mathrm{kg} / \mathrm{hafta}$ \\
\hline $25-29.9 \mathrm{~kg} / \mathrm{m}^{2}$ (Hafif Şişman) & $7-11.5 \mathrm{~kg}$ & $0.28(0.23-0.33) \mathrm{kg} / \mathrm{hafta}$ \\
\hline$\geq 30 \mathrm{~kg} / \mathrm{m}^{2}$ (Obez) & $5-9 \mathrm{~kg}$ & $0.22(0.17-0.27) \mathrm{kg} / \mathrm{hafta}$ \\
\hline
\end{tabular}


Diyet örüntüsünde enerjinin \%50-60’ı karbonhidrat, \%12-15'i protein ve \%25-30'u yağlardan sağlanmalıdır. Glisemik kontrolü sağlamak amacıyla, glisemik indeksi düşük ve orta derecede olan karbonhidrat kaynakları kullanılmalıdır (19). Karbonhidrat alımı gebelikte, en az 175 g/gün olmalıdır (21). Posa içeriği yüksek besinler postprandiyal glisemi kontrolüne yardımcı olduğundan DM’li gebelerde 28 g/gün posa tüketimi önerilmektedir (19,21). Protein gereksinmesi, normal bir gebenin yaşına ve tükettiği diyet protein kalitesine göre değişkenlik gösterse de günde en az 71 g protein alımı önerilmektedir. Diyabetli gebeler için ise önerilen protein gereksinmesi $1.1 \mathrm{~g} / \mathrm{kg} / \mathrm{gün}$ (ek 25 g/gün)'dür (21). Diyetteki yağ kaynaklarının \%5-7'si doymuş, \%12-15’i tekli doymamış yağ asidi ve \%810'u çoklu doymamış yağ asitlerinden sağlanmalıdır (19). Gebelik süresince alınması gereken linoleik asit miktarı 13 g/gün ve $\alpha$ - linolenik asit miktarı 1.4 g/gün olarak belirtilmektedir (21).

\section{FETAL PROGLAMLAMA}

'Fetal Programlama' veya 'Fetal Orijinler Hipotezi' ilk olarak 1970’lerde Helsinki Doğum Kohort Çalışması ve 1944'te yapılan Hollanda Kitlığı Doğum Kohort Çalışması'ndan elde edilen epidemiyolojik verilerin incelenmesi ile tanınmıştır (23). Fetal programlama, doku ve organ oluşumunun gerçekleştiği kritik bir dönem olan, embriyonik ve fetal gelişim sırasında gerçekleşmektedir (24). Bu dönemde ortaya çıkan yetersiz beslenme ve endokrin değişiklikler, metabolik ve fizyolojik değişikliklere yol açarak kişilerin erişkin hayatta çeşitli hastalıklara yatkın hale gelmesine neden olmaktadır (19,24). 1992 yllında Hales ve Barker (25), fetal ve erken bebeklik dönemindeki yetersiz beslenmenin Langerhans adacıklarının is hücresinin gelişimi üzerinde zararlı etkileri olduğu hipotezini ortaya koymuşlardır. Aynı bilim insanları, 1993 yılında (26), yalnızca tip 2 DM’nin değil aynı zamanda hipertansiyon ve hiperlipidemi gibi kardiyovasküler hastalık ve metabolik sendrom bileşenlerinin de fetal programlama ile ortaya çıkabileceğini göstermişlerdir. İlerleyen yıllarda fetal programlanmanın; sadece yetersiz beslenme ile değil, aşırı beslenme ve maternal DM’ye maruziyet gibi kötü çevresel koşullar ile de ilişkili olduğu düşünülmüştür (27).

Plasenta, anne ve fetüs arasında yer alan fetal büyüme için gerekli önemli bir yapıdır. Fetüs beslenmesine yönelik kanal görevi görmesinin yanı sıra immün ve metabolik fonksiyonlara da sahiptir. Diyabetik ortam, plasental büyümeyi ve gelişimi etkileyerek programlamaya neden olabilir. Bu etki DM'nin ortaya çıkış zamanı ile yakından ilgilidir. Gestasyonel DM genellikle geç plasental süreçler üzerinde etkili olurken, pregestasyonel DM ilk trimesterden itibaren etkilidir. İlk trimester; hiperglisemi, hiperinsülinemi ve artmış insülin benzeri büyüme faktörü-1 düzeyleri ile karakterizedir. Değişen plasental fonksiyon; erken dönemde gebelik kaybı, büyümenin kısıtlanması, preeklampsi riskinin artışı ve plasentamegaliye yol açabilir. İnvazyon, anjiogenez ve proliferasyon ile ilişkili süreçlerde yer alan matriks metalloproteinaz (MT1-MMP) plasental miktarı tip 1 DM’li gebeliğin ilk trimesterinde yükselmektedir. Diyabetik gebelerde tavsiye edilen günlük insülin dozu plasentadaki aktif MT1-MMP ekspresyonu ile ilişkilidir. Normal plasentada aktif MT1-MMP seviyesi ilk trimesterde azalırken, tip 1 DM'de azalmamaktadır. Gebeliğin ilerleyen dönemlerinde glikojen ve lipid gibi besin maddelerinin depolanması etkilenmektedir. Tüm bu değişiklikler sonucunda ortaya çıkan plasental değişiklikler fetal fenotipe katkıda bulunmaktadır (28).

İntrauterin dönemde hiperglisemiye maruz kalmak, çocukların gelecekteki sağlığına zarar vermektedir (29). Diyabetik annelerin bebeklerinin sonraki yaşamlarında; artmış kardiyovasküler morbidite, nörogelişimsel değişiklikler, metabolik sendrom, hipertansiyon, değişmiş lipid profili ve yağlı karaciğer gibi erişkin hastalıklarında fetal programlama etkisi yaşadıkları düşünülmektedir (30-34). Gestasyonel DM ile karşılaştırıldığında pregestasyonel DM'de fetal programlanmanın etkisi daha belirgin olabilir. Yapılan bir çalışmada, pregestasyonel DM'li kadınlardan doğan bebeklerde konjenital malformasyon riski \%9.5 iken gestasyonel DM'de \%5.7 olarak belirlenmiştir 
(30). Ayrıca, genç başlangıçlı tip 2 DM'li annelerden doğan bebeklerin $\$$ s hücre fonksiyonlarında azalma olduğu belirlenmiştir (29). Bu sonuçlar, anne karnında maternal hiperglisemiye maruziyetin fetal programlamaya etkisini göstermektedir. Tip 1 ve tip 2 DM'li gebelerde maternal glisemik kontrolün fetal beyin üzerindeki etkisi incelendiğinde, diyabetik annelerde fetal beyin aktivitesinin referans gruba göre değiştiği gözlemlenmiştir (31). Tip 1 DM’li annelerin fetüslerinde beyin aktivite gruplarının üçünde referans gruba göre önemli farklılıklar görülmüştür. İyi glisemik kontrole sahip (HbA1c <\%6) tip 2 DM'li grupta, referans ve zaylf kontrol grubunun (HbA1c >\%6) değerleri arasında bir ölçüm elde edilmiştir. Diyabetli gebeler iyi glisemik kontrole sahip olsalar bile fetal beyin aktiviteleri değişmektedir (31). Benzer şekilde, HbA1c değerleri sağlıklı kontroller ile farklılık göstermese bile tip 1 DM'li gebelerin çocuklarının 7 yaşında fazla kilolu veya obez olma riski artmaktadır (32). Tip 1 DM'li gebelerin yeni doğan bebeklerinde sağlıklı kontrollere göre kalp hızı değişkenliğinin azaldığı belirlenmiştir. Bu azalma; fetal asidemi, umbilikal kord glukoz değerleri ve maternal glisemik kontrol ile anlamlı olarak ilişkili bulunmuştur (33). Ayrıca, maternal tip 1 DM'li annelerin çocuklarının prospektif olarak incelendiği bir çalışmada, gebelik öncesi BKİ ve maternal tip 1 DM'ye sahip olmanın çocuklardaki yağlı karaciğer riskini artırdığı belirlenmiştir (34).

\section{SONUÇ VE ÖNERILER}

Nörogelişimsel bozuklukların yanı sıra obezite, DM, kardiyak anomaliler gibi birçok erişkin hastalı̆̆ı, intrauterin dönemde hiperglisemiye maruziyet yoluyla programlanabilir. Gestasyonel DM'ye göre pregestasyonel DM'nin etkileri daha çarpıcı sonuçlarla karşımıza çıkmaktadır. Bu nedenle, tip 1 ve tip 2 DM'li gebelerin fetal programlanmanın önemini anlamaları ve optimal glisemik kontrolü sağlamaları oldukça önemlidir. Pregestasyonel dönemde fetüs için uygun bir ortam oluşana kadar aile planlaması yapılmalıdır. Gestasyonel dönemde ise insülin, egzersiz ve tıbbi beslenme tedavisi ile kombine şekilde DM yönetimi sağlanmalıdır. Sağlıklı gebelere benzer şekilde DM'li gebelerde de gebelik önceki BKİye göre uygun vücut ağırlık kazanımı sağlanmalıdır. Özellikle bu dönemde fazla ya da yetersiz vücut ağırlığı kazanımı erişkin dönemde ortaya çıkabilecek hastalıklar için risk oluşturur. Gebelik sürecinde yapılan etkili müdahalelerin, fetal programlamaya engel olarak bebek sağlığını olumlu yönde etkileyeceği düşünülse de iyi kontrollü DM'li gebelerin çocuklarında da ortaya çıkabilen olumsuz sonuçlar düşündürücüdür. Diyabetli kadınlarda fetal programlamanin temelinde yer alan mekanizmalar henüz net bir şekilde aydınlatılamamıştır. Şu andaki bilgiler ışı̆̆ında, pregestasyonel DM'li gebeliklerde gebelik öncesi ve sırasında insülin, egzersiz ve tıbbi beslenme tedavisini kapsayan kombine DM yönetimi ile maternal hiperglisemiyi önlemek en faydalı yaklaşım olacaktır.

Çıkar çatışması - Conflict of interest: Yazarlar çıkar çatışması olmadığını beyan ederler. - The authors declare that they have no conflict of interest.

\section{KAYNAKLAR}

1. International Diabetes Federation. Diabetes Atlas. 9th ed. 2019. Available at: https://www.diabetesatlas.org/ upload/resources/2019/IDF_Atlas_9th_Edition_2019.pdf Accessed: 20.06.2020

2. Öztürk Ünsal İ, Çakal E. Pregestasyonel diyabet. In: Çakal E, editor. Gebelik ve diyabet 1. Baskı. ed. Ankara: Türkiye Klinikleri; 2020. p. 14-8.

3. American College of Obstetricians and Gynecologists. ACOG Practice Bulletin No. 201: Pregestational Diabetes Mellitus. Obstet Gynecol. 2018;132(6):e228-e48.

4. Shub A, Lappas M. Pregestational diabetes in pregnancy: Complications, management, surveillance, and mechanisms of disease-A review. Prenat Diagn. 2020.

5. Egan AM, McVicker L, Heerey A, Carmody L, Harney F, Dunne FP. Diabetic retinopathy in pregnancy: A population-based study of women with pregestational diabetes. J Diabetes Res. 2015;2015:310239.

6. Temple RC, Aldridge VA, Sampson MJ, Greenwood RH, Heyburn PJ, Glenn A. Impact of pregnancy on the progression of diabetic retinopathy in Type 1 diabetes. Diabet Med. 2001;18(7):573-7.

7. Kelly CB, Hookham MB, Yu JY, Jenkins AJ, Nankervis AJ, Hanssen KF, et al. Subclinical first trimester renal abnormalities are associated with preeclampsia in 
normoalbuminuric women with type 1 diabetes. Diabetes Care. 2018;41(1):120-7.

8. Tsakiridis I, Mamopoulos A, Athanasiadis A, Kourtis A, Dagklis T. Management of pregestational diabetes mellitus: A comparison of guidelines. J Matern Fetal Neonatal Med. 2020:1-10.

9. Sweeting AN, Ross GP, Hyett J, Molyneaux L, Constantino $\mathrm{M}$, Harding AJ, et al. Gestational diabetes mellitus in early pregnancy: Evidence for poor pregnancy outcomes despite treatment. Diabetes Care. 2016;39(1):75-81

10. Mackin ST, Nelson SM, Kerssens JJ, Wood R, Wild $S$, Colhoun HM, et al. Diabetes and pregnancy: National trends over a 15 year period. Diabetologia. 2018;61(5):1081-8.

11. Battarbee AN, Venkatesh KK, Aliaga S, Boggess KA. The association of pregestational and gestational diabetes with severe neonatal morbidity and mortality. J Perinatol. 2020;40(2):232-9.

12. Lock MC, Botting KJ, Tellam RL, Brooks D, Morrison JL. Adverse intrauterine environment and cardiac mirna expression. Int J Mol Sci. 2017;18(12).

13. Chen P, Piaggi P, Traurig M, Bogardus C, Knowler WC, Baier LJ, et al. Differential methylation of genes in individuals exposed to maternal diabetes in utero. Diabetologia. 2017;60(4):645-55.

14. Wang X, Lu J, Xie W, Lu X, Liang Y, Li M, et al. Maternal diabetes induces autism-like behavior by hyperglycemia-mediated persistent oxidative stress and suppression of superoxide dismutase 2. Proc Natl Acad Sci U S A. 2019;116(47):23743-52.

15. Türkiye Endokrinoloji ve Metabolizma Derneği (TEMD) Diabetes Mellitus Çalışma ve Eğitim Grubu. Diabetes Mellitus ve Komplikasyonlarını Tanı, Tedavi ve İzlem Kılavuzu. Ankara: Bayt Matbaası; Nisan 2019.

16. American Diabetes Association. 14. Management of diabetes in pregnancy: Standards of medical care in diabetes-2020. Diabetes Care. 2020;43(Supplement 1):S183-S92.

17. National Institute for Health and Care Excellence: Clinical Guidelines. Diabetes in pregnancy: management from preconception to the postnatal period. London: National Institute for Health and Care Excellence (UK).

18. Nielsen LR, Ekbom P, Damm P, Glümer C, Frandsen MM, Jensen DM, et al. HbA1c levels are significantly lower in early and late pregnancy. Diabetes Care 2004;27(5):12001.

19. Köksal G, Gökmen Özel H. Çocuk Hastalıklarında Beslenme Tedavisi. Ankara: Hatiboğlu Yayınevi; 2019. s. 39-326

20. Di Biase N, Balducci S, Lencioni C, Bertolotto A, Tumminia A, Dodesini AR, et al. Review of general suggestions on physical activity to prevent and treat gestational and pre- existing diabetes during pregnancy and in postpartum. Nutr Metab Cardiovasc Dis. 2019;29(2):115-26.

21. Diyabet Diyetisyenliği Derneği. Diyabetin Önlenmesi ve Tedavisinde Kanıta Dayalı Beslenme Rehberi-2019. İstanbul; 2019.

22. Institute of Medicine. Weight gain during pregnancy: Reexamining the guidelines. Washington, DC: National Academies Press; 2009.

23. Berry DC, Boggess K, Johnson QB. Management of pregnant women with type 2 diabetes mellitus and the consequences of fetal programming in their offspring. Curr Diab Rep. 2016;16(5):36.

24. Kwon E, Kim YJ. What is fetal programming?: A lifetime health is under the control of in utero health. Obstet Gynecol Sci. 2017;60(6):506-19.

25. Hales CN, Barker DJ. Type 2 (non-insulin-dependent) diabetes mellitus: The thrifty phenotype hypothesis. Diabetologia. 1992;35(7):595-601.26.

26. Barker DJ, Hales CN, Fall CH, Osmond C, Phipps K, Clark PM. Type 2 (non-insulin-dependent) diabetes mellitus, hypertension and hyperlipidaemia (syndrome $\mathrm{X})$ : Relation to reduced fetal growth. Diabetologia. 1993;36(1):62-7.

27. Finer S. Fetal programming via maternal diabetes: The controversy continues. Diabet Med. 2015;32(3):291-4.

28. Hiden U, Desoye G. The Placenta in a diabetic pregnancy. J Reproduktionsmed Endokrinol. 2010;7 (1): 27-33.

29. Singh R, Pearson E, Avery PJ, McCarthy MI, Levy JC, Hitman GA, et al. Reduced beta cell function in offspring of mothers with young-onset type 2 diabetes. Diabetologia. 2006;49(8):1876-80.

30. Aberg A, Westbom L, Källén B. Congenital malformations among infants whose mothers had gestational diabetes or preexisting diabetes. Early Hum Dev. 2001;61(2):8595.

31. Avci R, Whittington JR, Blossom SJ, Escalona-Vargas D, Siegel ER, Preissl HT, et al. Studying the effect of maternal pregestational diabetes on fetal neurodevelopment using magnetoencephalography. Clin EEG Neurosci. 2020:1550059420909658.

32. Lindsay RS, Nelson SM, Walker JD, Greene SA, Milne G, Sattar N, et al. Programming of adiposity in offspring of mothers with type 1 diabetes at age 7 years. Diabetes Care. 2010;33(5):1080-5.

33. Russell NE, Higgins MF, Kinsley BF, Foley ME, McAuliffe FM. Heart rate variability in neonates of type 1 diabetic pregnancy. Early Hum Dev. 2016;92:51-5.

34. Knorr S, Bytoft B, Lohse Z, Boisen AB, Clausen TD, Jensen RB, et al. Fatty liver among adolescent offspring of women with type 1 diabetes (the EPICOM Study). Diabetes Care. 2019;42(8):1560-8. 